\title{
Polyploid giant cancer cells with budding and the expression of cyclin E, S-phase kinase-associated protein 2, stathmin associated with the grading and metastasis in serous ovarian tumor
}

\author{
Hongcheng Lv ${ }^{1 \dagger}$, Yang Shi ${ }^{2 \dagger}$, Li Zhang ${ }^{1 \dagger}$, Dan Zhang ${ }^{1}$, Guang Liu' ${ }^{1}$ Zhengduo Yang ${ }^{1}$, Yan Li ${ }^{3}$, Fei Fei ${ }^{1}$ \\ and Shiwu Zhang ${ }^{1 *}$
}

\begin{abstract}
Background: We previously reported that polyploid giant cancer cells (PGCCs) exhibit cancer stem cell properties and express cell cycle-related proteins. HEY PGCCs induced by cobalt chloride generated daughter cells and the daughter cells had a strong migratory and invasive ability. This study is to compare the expression of cyclin E, S-phase kinase-associated protein 2 (SKP2), and stathmin between PGCCs with budding and control HEY cells, and determine the clinicopathological significance of cell cycle-related protein expression in ovarian tumors.

Methods: We used western blot and immunocytochemical staining to compare the expression levels of cyclin $E$, SKP2 and stathmin between PGCC with budding daughter cells and control HEY cells. In addition,

immunohistochemical staining for cyclin E, SKP2 and stathmin was performed on a total of 80 paraffin-embedded serous ovarian tumor tissue samples. The samples included 21 cases of primary high-grade carcinoma (group I) and their metastatic tumors (group II), 26 cases of primary low-grade carcinoma without metastasis (group III), and 12 cases of serous borderline cystadenoma (group IV).
\end{abstract}

Results: Single PGCC with budding in the stroma showed high correlation with the metastasis of ovarian carcinoma. Group I had a significantly higher number of single PGCCs with budding in the stroma than group III (85.71\% [18/21] vs. $23.08 \%[6 / 26]$ cases; $X^{2}=18.240, P=0.000$ ). The expression of cyclin $E$, SKP2, and stathmin was compared among the four groups. The expression levels of cyclin E, SKP2, and stathmin increased with the malignant grade of ovarian tumors and group II had the highest expression levels. The expression of cyclin $E\left(X^{2}=17.985, P=0.000\right)$, SKP2 $\left(X^{2}=12.384\right.$, $P=0.000)$, and stathmin $\left(X^{2}=20.226, P=0.000\right)$ was significantly different among the 4 groups.

Conclusions: These data suggest that the cell cycle-related proteins cyclin E, SKP2, and stathmin may be valuable biomarkers to evaluate the metastasis in patients with ovarian serous carcinoma.

\section{Background}

Ovarian cancer $(\mathrm{OC})$ is the fourth leading cause of cancer-related death among women in the United States. Ovarian serous carcinoma (OSC), the main histologic type of epithelial OC, has a poor 5-year overall survival rate [1]. Understanding the molecular mechanisms of ovarian carcinogenesis and metastasis is critical for the clinical

\footnotetext{
* Correspondence: zhangshiwu666@aliyun.com

'Equal contributors

'Department of Pathology, Tianjin Union Medicine Center, Tianjin 300121, P.R China

Full list of author information is available at the end of the article
}

diagnosis, treatment and prognosis evaluation [2]. Although, in most cases, the exact causes of OSC are unknown, the risk of developing OSC appears to be affected by several factors including familial and genetic factors, hormonal alterations, number of births, work-related stress, and environmental pollution [3-6]. Surgical excision and chemotherapy are the main treatment options for OSC. Chemoprevention holds promise for reducing cancer incidence and overcoming problems associated with the treatment of late-stage cancers [7]. However, OSC is associated with relatively high mortality rates because it 
lacks clear early detection or screening test, which means that many cases are diagnosed at advanced stages [8].

Polyploid giant cancer cells (PGCCs) are a special subpopulation of cancer cells that contribute to solid tumor heterogeneity and show significant variation in nuclei shape and number. We have previously demonstrated that PGCCs induced with cobalt chloride $\left(\mathrm{CoCl}_{2}\right)$ exhibit cancer stem cell properties and asymmetrically generate daughter cells via budding. By using iTRAQ proteomic analysis and immunohistochemical staining, we found that HEY PGCCs with budding daughter cells abnormally express cell cycle-related proteins compared with diploid HEY cancer cells. Expression levels of cyclin E and cyclin D1 were markedly higher in purified HEY PGCCs than those in the control HEY cells. PGCCs with budding showed the highest expression of cyclindependent kinase (CDK) 2 and cyclin B1 [9]. Furthermore, the daughter cells derived from PGCCs showed a stronger migratory and invasive ability than untreated diploid cells. Animal experiments also confirmed that tumors derived from PGCCs had a higher nucleus-tocytoplasm ratio and displayed mesenchymal changes compared with tumors derived from control HEY cells [10]. Based on iTRAQ proteomics analysis, western blot and immune staining, we confirmed that the expression of Cyclin E, SKP2, Stathmin in HEY PGCCs with budding daughter cells were higher than those in control HEY cells, which may provided new insight into how PGCCs and regular cancer cells are coordinately regulated in the progression of human ovarian carcinomas.

The cell-cycle related protein family consists of cyclins, CDKs, and cyclin-dependent kinase inhibitors (CDKIs). Cell cycle-related proteins play important roles in carcinogenesis, tumor development, and metastasis. Cyclin E forms a complex with CDK2 to regulate the progression of the cell cycle from the G1 to the S phase. This is the initial step in DNA replication and cell proliferation. Exogenous stimulators or abnormal molecular signals lead to upregulation of cyclin E expression, which shortens the G1 phase and allows the immediate entry of cells into the $\mathrm{S}$ phase. This alteration in the cell cycle increases cell proliferation and subsequent tumor formation. Lee et al. evaluated cyclin E expression in 78 cases of OSC, 72 cases of ovarian cystadenoma, and 55 cases of benign ovarian tumors [11]. They found that highest cyclin E protein expression was in OSC, followed by ovarian cystadenomas and benign ovarian tumors. These results suggest that the expression of cyclin $\mathrm{E}$ is positively associated with the development and histological grade of OSC. Davidson et al. reported that the cyclin E protein was overexpressed in OSC and associated with poor prognosis [12]. Together, these studies indicate that cyclin E may be a useful prognostic indicator for OC. Stathmin is involved in microtubule depolymerization. It promotes microtubules depolymerization or prevents microtubule polymerization in a phosphorylation-dependent manner during different stages of the cell cycle. Stathmin plays an important role in carcinogenesis, and it is highly expressed in breast cancer [13], prostate cancer [14], endocrine tumors [15], and ovarian carcinoma [16]. The expression of stathmin is closely related with cancer development and patient prognosis. S-phase kinase-associated protein 2 (SKP2) is a member of the F-box protein family, which specially recognizes and binds to phosphorylated substrates such as P27, P21, and E2F. SKP2 regulates the cell cycle mainly through the ubiquitin-proteasome pathway [17]. The expression of SKP2 has been closely associated with cancer development and metastasis [18]. Chiappetta et al. demonstrated that SKP2 overexpression was positively associated with the development of thyroid carcinoma [19]. Hung et al. reported that SKP2 protein overexpression increased cancer invasion and metastasis [20].

Many studies have described the expression of cyclin E, SKP2, and stathmin in OCs and investigated the correlation between cyclin E, SKP2, and stathmin expression and the clinicopathological characteristics of OC. Cell cycle-related proteins have been shown to induce PGCC formation and generate daughter cells with strong migratory ability. This study compared the expression of cyclin E, SKP2, and stathmin between PGCCs with budding and control HEY cells. We also determined the clinicopathological significance of cell cycle-related protein expression in OC.

\section{Methods}

\section{Cancer cell line and culture}

The human OC cell line HEY was purchased from the American Type Culture Collection (USA) and maintained in complete Eagle's minimum essential medium (EMEM) supplemented with fetal bovine serum and antibiotics (100 $\mathrm{U} / \mathrm{mL}$ penicillin, and $100 \mu \mathrm{g} / \mathrm{mL}$ streptomycin).

\section{Generation of PGCCs}

HEY cells were cultured in complete EMEM in T75 flasks until they reached $90 \%$ confluence. Cells were treated with $450 \mu \mathrm{M}$ of $\mathrm{CoCl}_{2}$ Sigma-Aldrich, St. Louis, MO, USA) for $48 \mathrm{~h}$, as described previously [10]. After rinsing with $1 \times$ phosphate-buffered saline (PBS), the cells were cultured in regular EMEM. Most regular-sized HEY cells died following $\mathrm{CoCl}_{2}$ treatment, whereas scattered PGCCs survived the $\mathrm{CoCl}_{2}$ treatment. Ten to 14 days later, PGCCs $\left(1 \times 10^{4}\right)$ with newly budding daughter cells $\left(1 \times 10^{5}\right)$ were used for western blot analysis and immunocytochemical staining.

\section{Western blot analysis}

Western blot analyses were done as described previously [9]. Cell extracts obtained from $\mathrm{CoCl}_{2}$-treated control HEY cells, HEY PGCCs (10\%), and HEY PGCCs with 
budding cells (90\%) were lysed in ice-cold buffer. The proteins were separated on a $10 \%$ sodium dodecyl sulfatepolyacrylamide gel and transferred to a polyvinylidene fluoride membrane (PVDF Membrane; GE Healthcare, USA). The membranes were blocked with $5 \%$ nonfat milk in $1 \times$ tris-buffered saline with $0.1 \%$ Tween- 20 for $1 \mathrm{~h}$ at room temperature, incubated with mouse anti-cyclin $\mathrm{E}$ (1:500 dilution; SC-247, Santa Cruz Biotechnology) and rabbit anti-SKP2 (1:100 dilution; SC-7164, Santa Cruz Biotechnology) antibodies overnight at $4^{\circ} \mathrm{C}$, and then with the appropriate secondary antibody for $1 \mathrm{~h}$ at room temperature. Protein expression was detected by using mixed ECL Plus reagents (RPN2132OL/AK, GE Life Sciences Co.) and the X-OMAT 2000 film processor. $\beta$ actin was used as a protein loading control.

\section{Tissue samples}

Paraffin-embedded human OSC tissue samples accumulated between 2005 and 2013 were obtained from the Tumor Tissue Bank of the Tianjin Union Medicine Center. None of the patients had been treated before surgical excision. OSCs were graded according to the two-tier system, which is based primarily on the assessment of nuclear atypia, with the mitotic rate used as a secondary feature [21] and the information of TNM staging system for these OSC listed in Additional file 1: Table S1. The tumor diagnosis was verified by two pathologists. Cases of high-grade OSCs with metastasis, low-grade OSCs without metastasis, and serous cystadenomas were included in the study. The tumors were divided into 4 groups according to their pathologic characteristics: groups I and II, 21 cases of primary cancer (patient mean age of $57.57 \pm 10.59$, mean tumor size $149.21 \pm 221.05 \mathrm{~mm}^{3}$ ) and their corresponding metastatic tumors (mean tumor size, $127.55 \pm 221.25 \mathrm{~mm}^{3}$ ); group III, 26 cases of primary cancer without metastasis (patient mean age of $56.77 \pm 10.80$, mean tumor size, $624.22 \pm$ $772.49 \mathrm{~mm}^{3}$ ); and group IV, 12 cases of borderline serous cystadenomas (patient mean age of $44.75 \pm 18.19$, mean tumor size, $769.69 \pm 1502.98 \mathrm{~mm}^{3}$ ). The study was approved by the Tianjin Union Medicine Center Research Committee, and the confidentiality of patient information has been maintained.

\section{Tissue microarray}

Formalin-fixed, paraffin-embedded tissues from the OC samples were stained with standard hematoxylin and eosin, and tumor tissues without necrosis were used to construct a tissue microarray with $1.5 \mathrm{~mm}$ cores ( $2.0 \mathrm{~mm}$ between cores). Two cores from every tumor sample were included in the tissue microarray. The tissue microarray block was sectioned for immunohistochemical (IHC) staining.

\section{Immunocytochemical (ICC) and IHC staining}

ICC and IHC staining was performed using an avidinbiotin-peroxidase complex as described previously [22]. For ICC staining, HEY PGCCs with budding and control HEY cells were grown on glass coverslips until 70\% confluence, washed with PBS, and fixed with cold $75 \%$ ethanol for $10 \mathrm{~min}$ on ice. The cells were incubated in $0.3 \%$ hydrogen peroxide for $10 \mathrm{~min}$ and then in 1.5\% normal goat serum to block endogenous peroxidase activity and nonspecific protein binding. The cells were incubated with rabbit monoclonal anti-stathmin antibody (1:100 dilution; Epitomics, USA) overnight at $4^{\circ} \mathrm{C}$ in a humidified chamber. The following morning, the cells were incubated with biotinylated goat anti-mouse IgG for $30 \mathrm{~min}$ and counterstained with hematoxylin. For IHC staining, 4- $\mu \mathrm{m}$-thick sections were deparaffinized in xylene and incubated in 3\% hydrogen peroxide to block endogenous peroxidase activity. Sections were washed with PBS and heated in citrate buffer (0.01 $\mathrm{M}$ of citric acid, $\mathrm{pH}$ 6.0) for $20 \mathrm{~min}$ at $95^{\circ} \mathrm{C}$ in an autoclave. After blocking nonspecific binding sites with $10 \%$ normal goat serum, sections were incubated overnight at $4^{\circ} \mathrm{C}$ with mouse monoclonal anti-cyclin $\mathrm{E}$ (1:50 dilution; MAB0019, Maixin. Bio, Fujian, China), mouse monoclonal antiSKP2 (1:50 dilution, ZM-0454, Zhongshan Inc., Beijing, China), and rabbit polyclonal anti-stathmin (1:50 dilution; RMA-0641, Maixin.Bio, Fujian, China,) antibodies. Following incubation, the sections were rinsed with PBS, incubated with biotinylated IgG for $20 \mathrm{~min}$ at $37^{\circ} \mathrm{C}$, incubated with 3 , 30-diaminobenzidine chromogen for 1-3 $\mathrm{min}$, and then washed with distilled water. Finally, all sections were counterstained with hematoxylin, dehydrated, and mounted.

\section{ICC and IHC scoring and quantification}

The evaluation of cyclin E, SKP2, and stathmin expression was quantified according to the method described by Sun et al. [23]. Both the intensity and percentage of positive cells were evaluated. Staining intensity was scored as follows: 0 , no staining; 1, weak positive (faint yellow staining); and 2, strong positive (brown staining). The number of positive cells was visually evaluated and stratified as follows: 0 (negative), $<10 \%$ positive cells; 1 (weak), $<30 \%$ positive cells; 2 (moderate), $<50 \%$ positive cells; and 3 (strong), $>70 \%$ positive cells. The sum of the staining intensity and positive cell scores was used to determine the staining index for each section.

\section{Statistical analysis}

SPSS 13.0 statistical software was used for all statistical analyses. A two-sided $P$-value of $<0.05$ was considered significant. The chi-squared test was used to compare differences in cell cycle-related protein expression between the groups. The Wilcoxon rank test was used to compare the correlation between the expressions of different protein in two different groups. 


\section{Results}

\section{$\mathrm{CoCl}_{2}$-induced PGCC formation}

We previously confirmed that diploid cells were selectively killed by high concentrations of $\mathrm{CoCl}_{2}$, whereas PGCCs survived from $\mathrm{CoCl}_{2}$ treatment. Compared with the $\mathrm{HEY}$ cells without treatment (Figure 1A-a), treatment of HEY cells with a high $\mathrm{CoCl}_{2}$ concentration $(450 \mu \mathrm{M})$ for $48 \mathrm{~h}$ killed most diploid cells, whereas PGCCs could be clearly visualized after removal of floating dead cells. PGCCs were obviously larger than control HEY cells (Figure 1A-b). Surviving PGCCs cultured in media with $10 \%$ serum generated daughter cells $10-14$ days after $\mathrm{CoCl}_{2}$ treatment. Figure $1 \mathrm{~A}-\mathrm{c}$ shows that $60 \%$ of the cells were regularsized cells and $40 \%$ were PGCCs. PGCCs generated daughter cells via budding. The number of regular-sized cells dramatically increased from $60 \%$ to $90 \%$ after 8 h of continuous culture in complete medium, whereas the number of PGCCs decreased from $40 \%$ to $10 \%$ (Figure 1A-d). These cells were analyzed for cell cycle-related protein expression.

\section{Cell cycle-related protein expression in control HEY cells and budding PGCCs}

Total proteins were extracted from control HEY cells and HEY PGCCs with budding. Western blot analysis showed that the expression levels of cyclin E and SKP2 were higher in HEY PGCCs with budding than in control HEY cells (Figure 1B). PGCCs with budding cells were trypsinized and grown on coverslips for $24 \mathrm{~h}$, and then fixed with $75 \%$ ethanol for ICC staining. The expression of stathmin was higher in PGCCs with budding (Figure 1C-a) than in control HEY cells (Figure 1C-b).

\section{Clinicopathological significance of single stromal PGCCs in human OSC}

By using the definition of PGCCs set by Zhang et al. that characterized a PGCC as a cancer cell with a nucleus of at least three times larger than that of a diploid cancer cell [10], it was observed that PGCCs with giant or multiple nuclei were present in both low-grade (Figure 2a) and high-grade human OSCs (Figure 2b). The shape of PGCC nuclei was irregular. In OC tissues and metastatic tumors, the size of the PGCC nuclei was 10-20 times larger than that of regular diploid cancer cell nuclei (Figure 2b). Interestingly, single PGCC invaded into the stroma. Figure 2c and $\mathrm{d}$ show a single PGCC invading into the stroma in low-grade and high-grade OSCs, respectively. Single PGCCs invading into the stroma were highly associated with tumor metastasis (Table 1). Single PGCCs invading into the stroma appeared in 18 of 21 high-grade OSCs

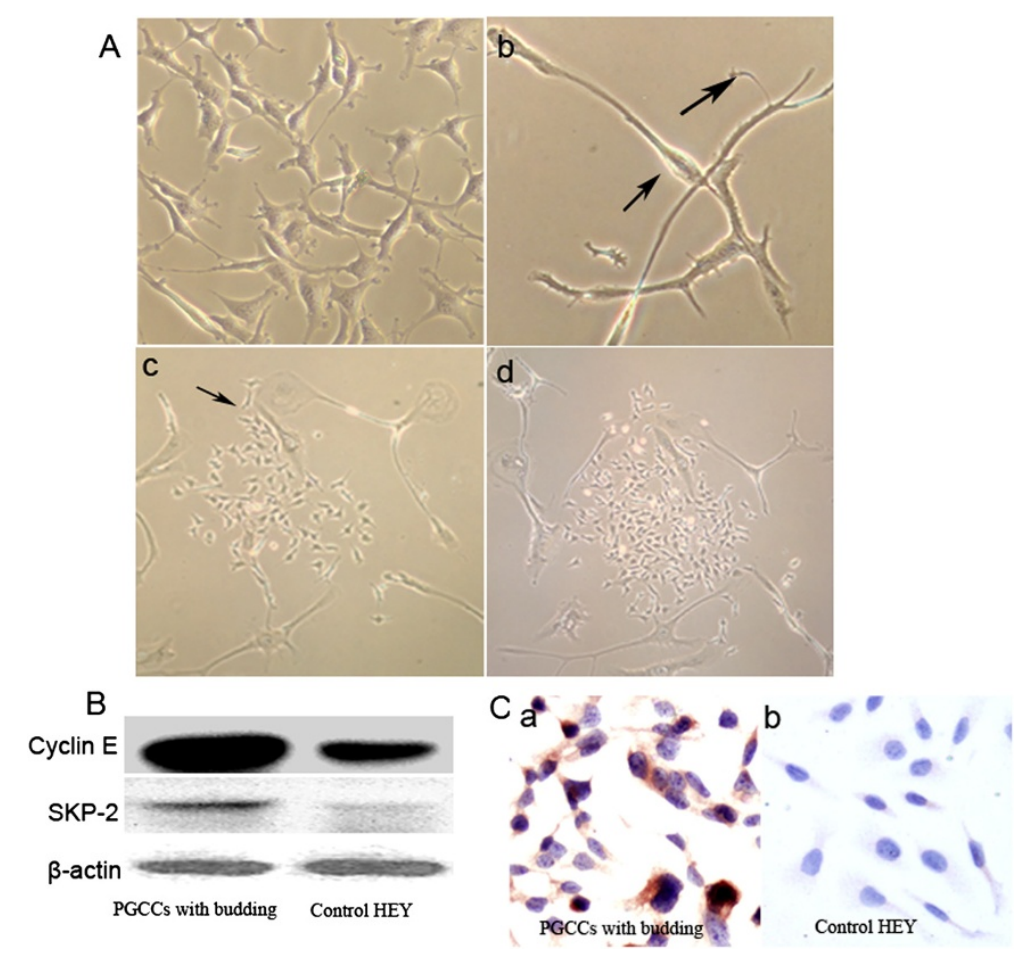

Figure 1 PGCCs with budding daughter cells. A. HEY PGCCs and control HEY cells. a. Control HEY cells ( $\times 400)$. b. HEY PGCCs induced by treatment with $450 \mu \mathrm{M}$ of $\mathrm{CoCl}_{2}$ for $48 \mathrm{~h}$ (small black arrow heads PGCCs; large black arrow heads budded daughter cells from PGCC; $\times 400$ ). c. PGCCS generated daughter cells via budding (black arrow heads budded daughter cells from PGCC; $\times 100)$. $\mathbf{d}$. PGCCs use budding for renewal and fast reproduction. Cells in panel 1 A-c were cultured in complete medium for $8 \mathrm{~h}(\times 100)$. B. Western blot of cyclin E and SKP2 expression in HEY PGCCS with budding and control HEY cells. C. ICC staining of stathmin in HEY PGCCs with budding and control HEY cells ( $\times 200)$. 


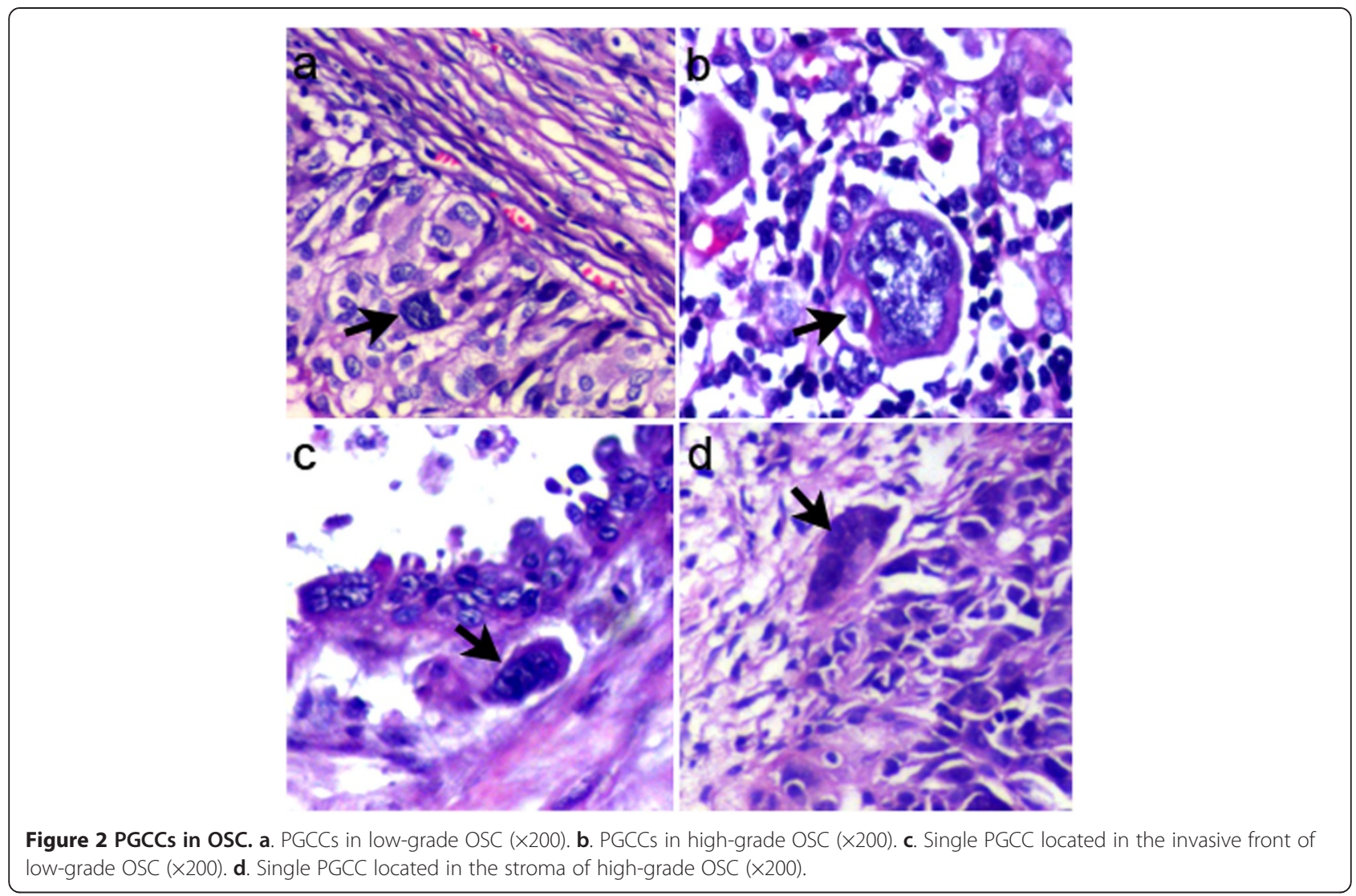

and 6 of 26 low-grade OSCs. This difference in the number of single PGCCs in the stroma between low-grade and high-grade OSCs was statistically significant $\left(X^{2}=18.240\right.$, $P=0.000$ ) (Table 2).

Expression of SKP2, cyclin E, and stathmin was associated with OSC grade

Eighty formalin-fixed, paraffin-embedded ovarian serous tumor tissues including cystoadenoma, low-grade OSC and high-grade OSC and their metastatic foci were used to construct a tissue microarray. IHC staining of cyclin E, SKP2, and stathmin was performed on the microarray slides. As shown in Figure 3, positive SKP2 (Figure 3a-d)

Table 1 Profile of single stromal PGCCs and lymph node metastasis in ovarian tumors

\begin{tabular}{llccc}
\hline & & \multicolumn{2}{c}{$\begin{array}{c}\text { Lymph node } \\
\text { metastasis }\end{array}$} \\
\cline { 3 - 5 } & & Yes & No \\
\hline $\begin{array}{c}\text { Primary ovarian tumor } \\
\text { with metastasis }\end{array}$ & Single stromal PGCCs & Yes & 18 & 0 \\
Primary ovarian tumor & Single stromal PGCC & Yes & 0 & 6 \\
without metastasis & & No & 0 & 20 \\
$\begin{array}{c}\text { Borderline serous } \\
\text { cystadenoma }\end{array}$ & Single stromal PGCC & Yes & 0 & 0 \\
& & No & 0 & 12 \\
\hline
\end{tabular}

and cyclin E (Figure $3 \mathrm{a}-\mathrm{d}$ ) staining was present in the nucleus of tumor cells, whereas positive stathmin staining was detected in the cytoplasm (Figure $3 \mathrm{i}-1$ ).

SKP2 $\left(\chi^{2}=12.384, P=0.006\right)$, cyclin $\mathrm{E}\left(\chi^{2}=17.985, P=\right.$ $0.000)$, and stathmin $\left(\chi^{2}=20.226, P=0.000\right)$ staining indexes were significantly different among the 4 groups (Table 3). The metastatic cancer cells from high-grade OSC had the highest SKP2, cyclin E, and stathmin staining indexes and borderline serous cystadenoma had the lowest (Table 4). Statistical analysis showed that the expression of SKP2 $(Z=-1.182, P=0.237)$, cyclin $\mathrm{E}(Z=-2.670, P=$ $0.008)$, and stathmin $(Z=-2.487, P=0.013)$ was higher in metastatic tumors than in primary high-grade OSCs. The staining index for cyclin E and stathmin was significantly different between group I and group II (Table 4). The expression of SKP2 $(Z=-2.450, P=0.014)$, cyclin E

Table 2 The differences of the percentage of tumor with single PGCC in the stroma

\begin{tabular}{lcccccc}
\hline & Group & $\mathbf{n}$ & $\begin{array}{c}\text { The percentage of } \\
\text { tumor with single } \\
\text { PGCC in the stroma }\end{array}$ & $\boldsymbol{x}^{\mathbf{2}}$ & $\boldsymbol{P}$ \\
\hline $\begin{array}{c}\text { Primary ovarian tumor } \\
\text { with metastasis }\end{array}$ & I & 21 & $85.71 \%(18 / 21)$ & 18.240 & 0.000 \\
$\begin{array}{c}\text { Primary ovarian tumor } \\
\text { without metastasis }\end{array}$ & III & 26 & $23.08 \%(6 / 26)$ & & \\
\hline
\end{tabular}




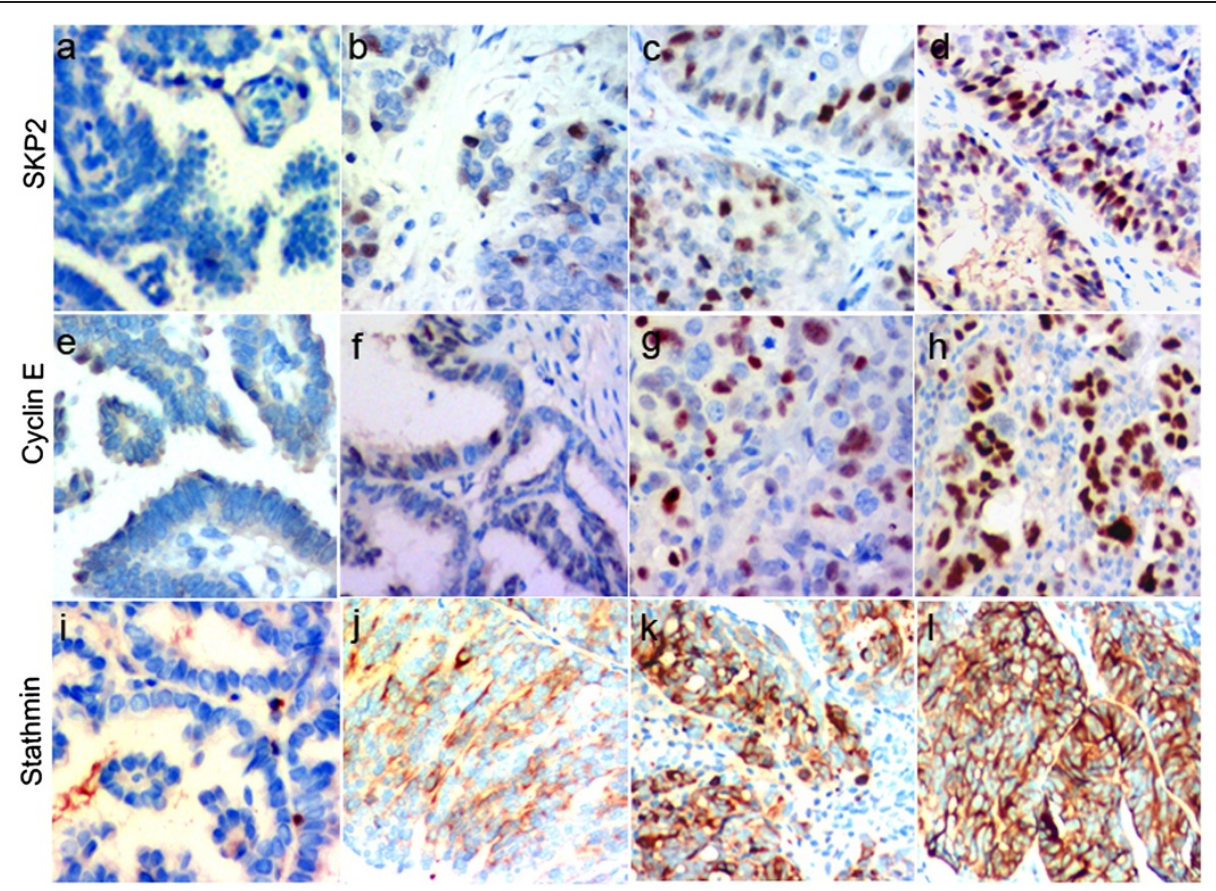

Figure 3 The expression of SKP2, cyclin E, and stathmin in OSC. SKP2 expression in (a) borderline ovarian serous cystadenoma, (b) low-grade OSC, (c) high-grade OSC, and (d) metastatic foci (×200). Cyclin E expression in (e) borderline ovarian serous cystadenoma, (f) low-grade OSC, (g) high-grade OSC, and (h) metastatic foci (×200). Stathmin expression in (i) borderline ovarian serous cystadenoma, (j) low-grade OSC, (k) high-grade OSC, and (I) metastatic foci $(\times 200)$.

$(Z=-2.068, P=0.039)$, and stathmin $(Z=-0.295, P=$ $0.768)$ was higher in primary low-grade ovarian carcinoma without metastasis than in borderline serous cystadenoma. The differences in SKP2 and cyclin E expression were statistically significant (Table 5).

\section{Correlation among SKP2, cyclin E, and stathmin protein expression in OSC}

To determine the association among SKP2, cyclin E, and stathmin protein expression in OSC, we performed a correlation analysis. Statistical analysis showed that the expression of SKP2 was positively correlated with cyclin $\mathrm{E}$ and stathmin expression. The correlation coefficient of

Table 3 The differences of stathmin, cyclin E and SKP-2 expression in the four groups of human ovarian tumors

\begin{tabular}{|c|c|c|c|c|c|}
\hline & Group & $\mathbf{n}$ & SKP-2 & Cyclin E & Stathmin \\
\hline $\begin{array}{l}\text { Primary ovarian tumor } \\
\text { with metastasis }\end{array}$ & 1 & 21 & $1.33 \pm 1.55$ & $2.57 \pm 2.13$ & $0.86 \pm 1.93$ \\
\hline $\begin{array}{l}\text { Corresponding } \\
\text { metastatic tumor }\end{array}$ & $\|$ & 21 & $1.95 \pm 1.74$ & $4.42 \pm 1.98$ & $1.95 \pm 2.15$ \\
\hline $\begin{array}{l}\text { Primary ovarian tumor } \\
\text { without metastasis }\end{array}$ & III & 26 & $0.88 \pm 0.99$ & $2.38 \pm 0.46$ & $0.27 \pm 0.87$ \\
\hline $\begin{array}{l}\text { Borderline serous } \\
\text { cystadenoma }\end{array}$ & IV & 12 & $0.17 \pm 0.38$ & $1.00 \pm 1.27$ & $0.17 \pm 0.57$ \\
\hline$x^{2}$ & & & 12.384 & 17.985 & 20.226 \\
\hline$P$ & & & 0.006 & 0.000 & 0.000 \\
\hline
\end{tabular}

SKP2 and cyclin E was 0.483 , which was statistically significant $(P=0.001)$. SKP2 expression was also positively and significantly correlated with stathmin expression (correlation coefficient, $0.320 ; P=0.028$ ).

\section{Discussion}

PGCCs contribute to solid tumor heterogeneity and play an important role in tumor initiation, metastasis and chemoresistance [10]. PGCCs are generally considered to be senescent or at the stage of mitotic catastrophe, our data demonstrated that these large cancer cells were actually live and generate the progeny cancer cells through budding $[10,24]$. The PGCCs could form through endoreduplication or cell fusion, reverting to regular cancer cells through splitting, budding, or burst-like mechanisms commonly used by simple organisms. PGCCs divided asymmetrically and

Table 4 The differences of stathmin, cyclin E and SKP-2 expression in primary ovarian tumor and their corresponding metastatic tumor

\begin{tabular}{cccccc}
\hline & Group & $\mathbf{n}$ & SKP-2 & Cyclin E & Stathmin \\
\hline $\begin{array}{c}\text { Primary ovarian tumor } \\
\text { with metastasis }\end{array}$ & I & 21 & $1.33 \pm 1.55$ & $2.57 \pm 2.13$ & $0.86 \pm 1.93$ \\
$\begin{array}{c}\text { Corresponding } \\
\text { metastatic tumor }\end{array}$ & II & 21 & $1.95 \pm 1.74$ & $4.42 \pm 1.98$ & $1.95 \pm 2.15$ \\
$Z$ & & & & & \\
$P$ & & & -1.182 & -2.670 & -2.487 \\
\hline
\end{tabular}




\begin{tabular}{|c|c|c|c|c|c|}
\hline & Group & $n$ & SKP-2 & Cyclin E & Stathmin \\
\hline $\begin{array}{l}\text { Primary ovarian tumor } \\
\text { without metastasis }\end{array}$ & III & 26 & $0.88 \pm 0.99$ & $2.38 \pm 0.46$ & $0.27 \pm 0.87$ \\
\hline $\begin{array}{l}\text { Borderline serous } \\
\text { cystadenoma }\end{array}$ & IV & 12 & $0.17 \pm 0.38$ & $1.00 \pm 1.27$ & $0.17 \pm 0.57$ \\
\hline Z & & & -2.450 & -2.068 & -0.295 \\
\hline$P$ & & & 0.014 & 0.039 & 0.768 \\
\hline
\end{tabular}

cycled slowly with a dynamic population [9,10,22]. They were positive for normal and cancer stem cell markers, and differentiated into adipose, cartilage, and bone. PGCCs induced by $\mathrm{CoCl}_{2}$ exhibit cancer stem cell properties and generate daughter cells via asymmetric division [10]. Daughter cells of PGCCs possess mesenchymal phenotypes and show stronger migratory and invasive ability than untreated diploid cells. The expression of cell cycle regulatory proteins including Cyclin E, SKP2, Stathmin, phosphorylated AKT, protein kinase $\mathrm{C}$, phosphoglycerate kinase 1, p38, and mitogen-activated protein kinase in PGCCs with budding daughter cells are higher than those in untreated diploid cells. Recent studies have made great progress in dissecting the role of cell cycle regulatory mechanisms in carcinogenesis and tumors metastasis. Impaired cell cycle regulation is thought to be actively involved in all stages of carcinogenesis. Cell cycle proteins (cyclins), CDKs, and CDKIs are the main cell cycle regulators during tumor progression [25]. In the present study, we investigated the expression of three cell cycle-related factors including cyclin E, SKP2, and stath$\mathrm{min}$, in OSC and their association with the OSC grade.

Cyclin E, an important member of the cyclin family, interacts with CDK2 to form a functional complex that promotes cell cycle progression. Cyclin E overexpression has been detected in various cancers, including breast cancer [26], gastric cancer [27], and colorectal cancer [28]. Session, et al. found that the expression of cyclin E was significantly higher in $\mathrm{OC}$ tissues than in benign ovarian tumors [29]. Furthermore, cyclin E expression was significantly upregulated in metastatic lymph nodes and ascites. Together, these findings indicate that overexpression of cyclin E is positively associated with $\mathrm{OC}$ development and invasion. Our study showed that cyclin $\mathrm{E}$ is upregulated in high-grade OSCs compared with low-grade OSCs and borderline ovarian serous cystadenomas. We also found that cyclin E expression was significantly higher in metastatic foci than in primary high-grade OSCs.

Increasing biochemical and genetic evidence suggests that SKP2 is involved in multiple stages of the cell cycle [30-32]. SKP2 specifically recognizes phosphorylated substrates and induces ubiquitin-mediated degradation $[33,34]$. Gstaiger showed that cotransfection of SKP2 and $\mathrm{H}$-Ras significantly increased tumor formation in an animal model [35]. Studies have shown that SKP2 overexpression was positively correlated with the histological grade of malignant carcinomas. Fotovati et al. reported that SKP2 overexpression was positively associated with tumor progression and negatively associated with patient prognosis [36]. In the present study, we detected SKP2 protein expression in ovarian tumors. Furthermore, we demonstrated that SKP2 protein was upregulated in high-grade OSC and metastatic foci compared with lowgrade OSCs and borderline serous cystadenoma. Our results suggest that SKP2 overexpression is associated with OSC metastasis and grade.

Stathmin promotes microtubule depolymerization or prevents microtubule polymerization in a phosphorylationdependent manner. Stathmin is negatively regulated by phosphorylation. Accordingly, a less phosphorylable stathmin point mutant impaired extracellular matrix-induced microtubule stabilization and conferred a higher invasive potential [37]. Belletti et al. reported that overexpression of stathmin protein promoted sarcoma cell migration into adjacent local tissues and metastasis to distant organs [37]. Singer et al. reported that overexpression of stathmin accelerated the proliferation of non-small cell lung cancer cells and promoted their invasion and migration into the stroma [38]. Wei et al. showed that the expression of stathmin was high in OC cells, particularly in metastatic tumor cells [16]. Our results showed that the metastatic foci of high-grade OSCs had the highest expression of stathmin, which was positively correlated with SKP2 expression.

Few studies have investigated the relationship between the formation of PGCCs and the expression of cell cyclerelated proteins cyclin E, SKP2, and stathmin in OSC. Cyclin $\mathrm{E}$ is among the main limiting factors controlling $\mathrm{S}$ phase entry of cells in G1 phase [39]. SKP2 helps cyclin E passing G1 checkpoint. Overexpressed SKP2 could combine with P27 to stimulate P27 ubiquitination and degradation via the ubiquitin-proteasome pathway [40]. Nelsen reported that co-transfection of cyclin E and SKP2 promoted S phase entry, DNA replication, and proliferation of liver cells [41]. The results of our study showed that the expression of cyclin E was positively correlated with the expression of SKP2 in OSC tissues. The expression of cyclin $\mathrm{E}$ reaches a peak in the late $\mathrm{G} 1$ or $\mathrm{S}$ phase and is absent in the G2/M phase. This indicates that cyclin $\mathrm{E}$ is not involved in the regulation of the G2/M phase, whereas SKP2 and stathmin play an important role in this phase. Stathmin phosphorylation/dephosphorylation controls cell cycle and cell motility. Stathmin is activated by simultaneous phosphorylation at the third or fourth phosphorylation sites in the G2/M phase. This step is essential for functional stathmin to facilitate cell transition from the G2 to M phase [42]. P27 interacts with stathmin to disrupt stathmin binding to tubulin, thereby inhibiting cell movement and microtubule polymerization. Upregulation of 
P27 in cancer cells inhibits stathmin protein expression to prevent the separation of stathmin from microtubules and promote the proliferative potential of cancer cells. SKP2 degrades P27 protein through ubiquitination, which promotes the expression of stathmin protein by reducing P27 inhibition $[43,44]$.

\section{Conclusions}

The current study serves as the rationale for further investigation of the role of cyclin E, SKP2, and stathmin protein in the development and metastasis of OC. Our study suggests that these cell cycle-related proteins may represent useful prognostic and metastatic indicators for OC patients.

\section{Additional file}

Additional file 1: Table S1. Conventional TNM staging system of the ovarian carcinomas.

\section{Competing interests}

The authors declare that they have no competing interests.

\section{Authors' contributions}

$H L$ and $Y S$ carried out the sample collection and drafted the manuscript. LZ and YL carried out the immunoassays. DZ, FF and GL participated in the design of the study and performed the statistical analysis. SZ conceived of the study, and participated in its design and coordination and helped to draft the manuscript. All authors read and approved the final manuscript.

\section{Acknowledgements}

This work was supported in part by grants from the Key Foundation of Tianjin Health Bureau (2013KR14) and the foundation of committee on science and technology of Tianjin (13JCYBJC42700).

\section{Author details}

'Department of Pathology, Tianjin Union Medicine Center, Tianjin 300121, P.R China. ${ }^{2}$ Department of Colorectal surgery, Tianjin Union Medicine Center, Tianjin 300121, P.R China. ${ }^{3}$ Department of Gynaecology and Obstetrics, Tianjin Union Medicine Center, Tianjin 300121, P.R China.

Received: 24 April 2014 Accepted: 5 August 2014

Published: 8 August 2014

\section{References}

1. Rauh-Hain JA, Diver EJ, Clemmer JT, Bradford LS, Clark RM, Growdon WB, Goodman AK, Boruta DM 2nd, Schorge JO, del Carmen MG: Carcinosarcoma of the ovary compared to papillary serous ovarian carcinoma: a SEER analysis. Gynecol Oncol 2013, 131(1):46-51.

2. Yin M, Li C, Li X, Lou G, Miao B, Liu X, Meng F, Zhang H, Chen X, Sun M, Ling Q, Zhou R: Over-expression of LAPTM4B is associated with poor prognosis and chemotherapy resistance in stages III and IV epithelial ovarian cancer. J Surg Oncol 2011, 104(1):29-36.

3. Palmer J, Jivraj S, Galimberti A, Paterson M: Serous ovarian carcinoma in pregnancy. BMJ Case Rep 2009, 2009. bcr04.2009.1809.

4. Demsky R, McCuaig J, Maganti M, Murphy KJ, Rosen B, Armel SR: Keeping it simple: genetics referrals for all invasive serous ovarian cancers. Gynecol Oncol 2013, 130(2):329-333.

5. George SH, Shaw P: BRCA and Early Events in the Development of Serous Ovarian Cancer. Front Oncol 2014, 4:5

6. Halperin R, Zehavi S, Langer R, Hadas E, Bukovsky I, Schneider D: Primary peritoneal serous papillary carcinoma: a new epidemiologic trend? A matched-case comparison with ovarian serous papillary cancer. Int J Gynecol Cancer 2001, 11(5):403-408.
7. Davidson B, Smith Y, Nesland JM, Kaern J, Reich R, Trope CG: Defining a prognostic marker panel for patients with ovarian serous carcinoma effusion. Hum Pathol 2013, 44(11):2449-2460.

8. Kim A, Ueda Y, Naka T, Enomoto T: Therapeutic strategies in epithelial ovarian cancer. J Exp Clin Canc Res: CR 2012, 31:14

9. Zhang S, Mercado-Uribe I, Hanash S, Liu J: iTRAQ-based proteomic analysis of polyploid giant cancer cells and budding progeny cells reveals several distinct pathways for ovarian cancer development. PloS One 2013, 8(11):e80120.

10. Zhang S, Mercado-Uribe I, Xing Z, Sun B, Kuang J, Liu J: Generation of cancer stem-like cells through the formation of polyploid giant cancer cells. Oncogene 2014, 33(1):116-128.

11. Lee YH, Heo JH, Kim TH, Kang H, Kim G, Kim J, Cho SH, An HJ: Significance of cell cycle regulatory proteins as malignant and prognostic biomarkers in ovarian epithelial tumors. Int J Gynecol Pathol 2011, 30(3):205-217.

12. Davidson B, Skrede M, Silins I, Shih le M, Trope CG, Florenes VA: Low-molecular weight forms of cyclin E differentiate ovarian carcinoma from cells of mesothelial origin and are associated with poor survival in ovarian carcinoma. Cancer 2007, 110(6):1264-1271.

13. Alli E, Yang JM, Hait WN: Silencing of stathmin induces tumor-suppressor function in breast cancer cell lines harboring mutant p53. Oncogene 2007, 26(7):1003-1012.

14. Mistry SJ, Atweh GF: Therapeutic interactions between stathmin inhibition and chemotherapeutic agents in prostate cancer. Mol Canc Therapeut 2006, 5(12):3248-3257.

15. Sadow PM, Rumilla KM, Erickson LA, Lloyd RV: Stathmin expression in pheochromocytomas, paragangliomas, and in other endocrine tumors. Endocr Pathol 2008, 19(2):97-103.

16. Wei SH, Lin F, Wang X, Gao P, Zhang HZ: Prognostic significance of stathmin expression in correlation with metastasis and clinicopathological characteristics in human ovarian carcinoma. Acta Histochem 2008, 110(1):59-65.

17. Fuster JJ, Gonzalez JM, Edo MD, Viana R, Boya P, Cervera J, Verges M, Rivera J, Andres V: Tumor suppressor p27(Kip1) undergoes endolysosomal degradation through its interaction with sorting nexin 6. FASEB J 2010, 24(8):2998-3009.

18. Deubzer HE, Ehemann V, Kulozik AE, Westermann F, Savelyeva L, Kopp-Schneider A, Riester D, Schwab M, Witt O: Anti-neuroblastoma activity of Helminthosporium carbonum (HC)-toxin is superior to that of other differentiating compounds in vitro. Cancer Lett 2008, 264(1):21-28.

19. Chiappetta G, De Marco C, Quintiero A, Califano D, Gherardi S, Malanga D, Scrima M, Montero-Conde C, Cito L, Monaco M, Motti ML, Pasquinelli R, Agosti V, Robledo M, Fusco A, Viglietto G: Overexpression of the S-phase kinase-associated protein 2 in thyroid cancer. Endocr Relat Cancer 2007, 14(2):405-420.

20. Hung WC, Tseng WL, Shiea J, Chang HC: Skp2 overexpression increases the expression of MMP-2 and MMP-9 and invasion of lung cancer cells. Cancer Lett 2010, 288(2):156-161.

21. Malpica A, Deavers MT, Lu K, Bodurka DC, Atkinson EN, Gershenson DM Silva EG: Grading ovarian serous carcinoma using a two-tier system. Am J Surg Pathol 2004, 28(4):496-504.

22. Zhang S, Mercado-Uribe I, Liu J: Tumor stroma and differentiated cancer cells can be originated directly from polyploid giant cancer cells induced by paclitaxel. Int J Cancer 2014, 134(3):508-518.

23. Sun B, Qie S, Zhang S, Sun T, Zhao X, Gao S, Ni C, Wang X, Liu Y, Zhang L: Role and mechanism of vasculogenic mimicry in gastrointestinal stromal tumors. Hum Pathol 2008, 39(3):444-451.

24. Zhang S, Mercado-Uribe I, Liu J: Generation of erythroid cells from fibroblasts and cancer cells in vitro and in vivo. Cancer Lett 2013, 333(2):205-212.

25. Fang F, Orend G, Watanabe N, Hunter T, Ruoslahti E: Dependence of cyclin E-CDK2 kinase activity on cell anchorage. Science 1996, 271(5248):499-502.

26. Scaltriti M, Eichhorn PJ, Cortes J, Prudkin L, Aura C, Jimenez J, Chandarlapaty S, Serra V, Prat A, Ibrahim YH, Guzman M, Gili M, Rodriguez O, Rodriguez S, Perez J, Green SR, Mai S, Rosen N, Hudis C, Baselga J: Cyclin E amplification/overexpression is a mechanism of trastuzumab resistance in HER2+ breast cancer patients. Proc Natl Acad Sci U S A 2011, 108(9):3761-3766.

27. Xiangming C, Natsugoe S, Takao S, Hokita S, Tanabe G, Baba M, Kuroshima K, Aikou T: The cooperative role of p27 with cyclin E in the prognosis of advanced gastric carcinoma. Cancer 2000, 89(6):1214-1219. 

gynecologic malignancies. Gynecol Oncol 1999, 72(1):32-37.

30. Demetrick DJ, Zhang H, Beach DH: Chromosomal mapping of the genes for the human CDK2/cyclin A-associated proteins p19 (SKP1A and SKP1B) and p45 (SKP2). Cytogenet Cell Genet 1996, 73(1-2):104-107.

31. Deshaies RJ: SCF and Cullin/Ring H2-based ubiquitin ligases. Annu Rev Cell Dev Biol 1999, 15:435-467.

32. Koepp DM, Harper JW, Elledge SJ: How the cyclin became a cyclin: regulated proteolysis in the cell cycle. Cell 1999, 97(4):431-434

33. Imaki H, Nakayama K, Delehouzee S, Handa H, Kitagawa M, Kamura T, Nakayama KI: Cell cycle-dependent regulation of the Skp2 promoter by GA-binding protein. Cancer Res 2003, 63(15):4607-4613.

34. Sicari BM, Troxell R, Salim F, Tanwir M, Takane KK, Fiaschi-Taesch N: c-myc and skp2 coordinate p27 degradation, vascular smooth muscle proliferation, and neointima formation induced by the parathyroid hormone-related protein. Endocrinology 2012, 153(2):861-872.

35. Gstaiger M, Jordan R, Lim M, Catzavelos C, Mestan J, Slingerland J, Krek W: Skp2 is oncogenic and overexpressed in human cancers. Proc Natl Acad Sci U S A 2001, 98(9):5043-5048.

36. Fotovati A, Abu-Ali S, Nakayama K, Nakayama Kl: Impaired ovarian development and reduced fertility in female mice deficient in Skp2. J Anat 2011, 218(6):668-677.

37. Belletti B, Nicoloso MS, Schiappacassi M, Berton S, Lovat F, Wolf K, Canzonieri V, D'Andrea S, Zucchetto A, Friedl P, Colombatti A, Baldassarre G: Stathmin activity influences sarcoma cell shape, motility, and metastatic potential. Mol Biol Cell 2008, 19(5):2003-2013.

38. Singer $S$, Malz M, Herpel E, Warth A, Bissinger M, Keith M, Muley T, Meister M, Hoffmann H, Penzel R, Gdynia G, Ehemann V, Schnabel PA, Kuner R, Huber $\mathrm{P}$, Schirmacher $\mathrm{P}$, Breuhahn $\mathrm{K}$ : Coordinated expression of stathmin family members by far upstream sequence element-binding protein-1 increases motility in non-small cell lung cancer. Cancer Res 2009, 69(6):2234-2243.

39. Koutsami MK, Tsantoulis PK, Kouloukoussa M, Apostolopoulou K, Pateras IS, Spartinou Z, Drougou A, Evangelou K, Kittas C, Bartkova J, Bartek J, Gorgoulis VG: Centrosome abnormalities are frequently observed in non-small-cell lung cancer and are associated with aneuploidy and cyclin E overexpression. J Pathol 2006, 209(4):512-521.

40. Deb-Basu D, Karlsson A, Li Q, Dang CV, Felsher DW: MYC can enforce cell cycle transit from $\mathrm{G} 1$ to $\mathrm{S}$ and $\mathrm{G} 2$ to $\mathrm{S}$, but not mitotic cellular division, independent of p27-mediated inihibition of cyclin E/CDK2. Cell Cycle 2006, 5(12):1348-1355.

41. Nelsen CJ, Hansen LK, Rickheim DG, Chen C, Stanley MW, Krek W, Albrecht JH: Induction of hepatocyte proliferation and liver hyperplasia by the targeted expression of cyclin E and skp2. Oncogene 2001, 20(15):1825-1831.

42. Honnappa S, Jahnke W, Seelig J, Steinmetz MO: Control of intrinsically disordered stathmin by multisite phosphorylation. J Biol Chem 2006, 281(23):16078-16083.

43. Steinmetz MO: Structure and thermodynamics of the tubulin-stathmin interaction. J Struct Biol 2007, 158(2):137-147.

44. Baldassarre G, Belletti B, Nicoloso MS, Schiappacassi M, Vecchione A, Spessotto P, Morrione A, Canzonieri V, Colombatti A: p27(Kip1)-stathmin interaction influences sarcoma cell migration and invasion. Cancer Cell 2005, 7(1):51-63.

\section{Submit your next manuscript to BioMed Central and take full advantage of:}

- Convenient online submission

- Thorough peer review

- No space constraints or color figure charges

- Immediate publication on acceptance

- Inclusion in PubMed, CAS, Scopus and Google Scholar

- Research which is freely available for redistribution

Submit your manuscript at www.biomedcentral.com/submit 